\title{
The Assesment of High Order Thinking Skills of Undergraduate Students in Biology Education Department
}

\author{
Maulana Khalid Riefani, Nurul Hidayati Utami \\ Department of Biology Education \\ Universitas Lambung Mangkurat \\ Banjarmasin, Indonesia \\ maulanakriefani@unlam.ac.id
}

\begin{abstract}
High order thinking skills include critical, logical, reflective, metacognitive, and creative thinking. They are activated when individuals encounter unfamiliar problems, uncertainties, questions, or dilemmas. Successful applications of the skills result in explanations, decisions, performances, and products that are valid within the context of available knowledge and experience and that promote continued growth in these and other intellectual skills. This research aimed to identify high order thinking skills of undergraduate students in Biology Education Department. This research was descriptive research (at the first academic year 2016/2017) in Biology Education Department, Universitas Lambung Mangkurat. This instrument was validated by expert judgment and tested toward 50 students. The results showed that the ability to analyze (C4), the ability to evaluate (C5), and the ability to create (C6) respectively were $31.81 \%, 69.88 \%$, $50.21 \%$. Overall the high-level thinking skills of students at Biology students is better.
\end{abstract}

Keywords: assesment, high order thinking, undergraduate students, biology education

\section{INTRODUCTION}

Education is a conscious process to transfer knowledge, insight, and experience to develop intellectuality. Biology learning requires an active role of learners based on scientific processes and ways of thinking based on facts. According to the assumption from learners, Biology is the science of rote and unbeneficial for their life. Biology emphasizes more on teaching and learning activities. Science of Biology develops the concepts and skills of learners' process with various teaching methods that are appropriate with the study materials that have been taught.

Biology education is one of the study programs in the Faculty of Teacher and Education that has students with different backgrounds. The differences in the background of learners underlie the differences in each learner's level of thinking ability. High-level abilities are the highest cognitive processes that learners have through complex processes and learning processes in their school.

High-level thinking as the transfer process of a problem and the problem is sought by the solution using critical thinking [1]. The cognitive level of the taxonomy Bloom, namely; understanding (C2) and applying (C3), as well as higher order thinking at the level of analyzing (C4), evaluating (C5), and creating (C6) [2].

Implementation of the learning process in the achievement of high-order thinking skills is less encouraging. The design curriculum in Indonesia leads to the extent of the material, so learners are directed to completion of the material. Learners are only asked to remember and memorize the material. In addition, based on assessment system with low cognitive level tests the students have a separate problem for the development of high-level thinking ability, even the national exam is considered as a medium for measuring the success of learners in high-level thinking.

High order thinking skills include critical, logical, reflective, metacognitive, and creative thinking. They are activated when individuals encounter unfamiliar problems, uncertainties, questions, or dilemmas. Successful applications of the skills result in explanations, decisions, performances, and products that are valid in the contexts of knowledge and experience.

High order questions with rich questions are needed to improve logical reasoning and thinking students, especially in the classroom learning process. Learners will use the knowledge, understanding, skills they possess, and they will connect the problems they have with the new situation that arises.

The profile of learners' level of thinking can be known through the testing of learners in solving the problems presented. High Level Questions (HLQ) are essential in identifying students' level of thinking. Based on the background, this research aimed to measure highorder thinking skills.

\section{METHOD}

The research was descriptive in order to identify and describe the thinking ability of educational biology students. The approach used was a quantitative approach. This research only measured the ability of high-level thinking (cognitive).

The research was conducted in Biology Education, Faculty of Teacher Training and Education Universitas Lambung Mangkurat, for three months (January-March) in the second semester of 2016/2017.

The research subjects were students of Biology Education FKIP ULM from 2016 batch. The research 
instrument was objective test. This research yields the overall average of learner's ability, maximum score, and minimum score. The average calculation uses the following equation:

$$
\mu=\frac{\Sigma x}{N}
$$

Where are $\mu=$ average score, $\Sigma x=$ amount of score learners, and $\mathrm{N}=$ amount of learners

The data analysis of students' ability was done using Microsoft Excel program. The criteria were divided into five categories. The establishment of graduation standards or competency achievement standards was adapted from Tanwey [3]. Reference used is as follows.

TABLE I. CRITERIA FOR ACHIEVING COMPETENCY STANDARDS

\begin{tabular}{|l|l|l|}
\hline \multicolumn{1}{|c|}{ No } & \multicolumn{1}{|c|}{ Average Scores } & \multicolumn{1}{c|}{ Category } \\
\hline 1. & $90 \% \leq x$ & A (very high) \\
\hline 2. & $75 \% \leq x<90 \%$ & B (high) \\
\hline 3. & $60 \% \leq x<75 \%$ & C (medium) \\
\hline 4. & $40 \% \leq x<60 \%$ & D (low) \\
\hline 5. & $x<40 \%$ & E (very low) \\
\hline
\end{tabular}

\section{RESULTS AND DISCUSSION}

The assessment results showed that the thinking ability of Biology Education students from 2016 batch in the second semester of 2016/2017 was included in the low category. The average score of the ability can be seen in Table 2 .

TABLE II. THE RESULTS OF BIOLOGY EDUCATION STUDENTS' ACHIEVEMENTS AND THEIR LEVEL

\begin{tabular}{|c|c|c|}
\hline $\begin{array}{c}\text { Cognitive } \\
\text { Level }\end{array}$ & $\begin{array}{c}\text { Percentage } \\
\mathbf{( \% )}\end{array}$ & Category \\
\hline C3 (application) & 39.39 & Low \\
\hline C4 (analysis) & 31.81 & Low \\
\hline C5 (evaluation) & 69.88 & Medium \\
\hline C6 (synthesis) & 50.21 & Low \\
\hline Average & $\mathbf{4 7 . 7 7}$ & Low \\
\hline
\end{tabular}

Based on Table 2, the percentage of students who have cognitive levels of $\mathrm{C} 3, \mathrm{C} 4$, and $\mathrm{C} 6$ in the low category, while the percentage of students who have cognitive level C5 was in the moderate category. The average percentage of all students was at low category. It is because the Biology students emphasize the process skills. Appropriate learning strategies for learners should be involved optimally (intellectually and emotionally).

Cognitive abilities at C5 level indicate that the students produce unique communication, produce a complete plan or activity, and produce a set of well abstract relationships, while the ability of applications, analysis, and evaluate are low, These results indicate the students do not have a high level of thinking ability.

Activities that use and familiarize the workings of the brain place its expertise that includes analysis, conclusion, and evaluation which are easy in enhancing high-order thinking skills [4].
Thinking skills are not only generated from college learning, but thinking skills start from the secondary school level and the relationships of the various fields of study. Other factors that cause low-level thinking ability are the learning process and repetition rate obtained from high school. Lessons learned in secondary schools have not led learners to high-level thinking targets. The teacher training exercises do not reflect the students' high-order thinking skills, the studenys are only given the ability to pass and complete the national exam questions.

Learning that supports high-thinking ability of learners is the replacement of learning patterns that provides the active participation of learners. Good Biology learning requires the development of science skills, the science process, and the attitudes of learners to science

\section{CONClusion And SugGestion}

The average percentage of students' high-order thinking ability reached $47.77 \%$, included in the low category. The evaluation ability (C5) had a relatively high percentage, while the low ability was C4 (31.81\%), C3 (39.39\%), and C6 (50.21\%), respectively.

Further research needs to conduct an interview on students, so that factors causing students' low level of thinking can be identified. In addition, the measurement of affective and psychomotor abilities of learners needs to be done. Advanced research should use subjective test instruments with open answers.

\section{REFERENCES}

[1] S. M. Brookhart, Asses Higher-Order-Thingking Skills In Your Classroom, Alexandria: ASCD, 2010.

[2] L. W. Anderson and D. R. Krathwohl, Kerangka Landasan Untuk Pembelajaran, Pengajaran, dan Assesmen (Terjemahan Agung Prihantoro), New York: Addition Wesley Longman, 2010.

[3] J. Tanwey and D. Gast, Single Subject Research in Special Education, Columbus, OH: Merrill, 1984.

[4] H. Gardner, Multiple Intelligences (Terjemahan Yelvi Andri Zaimul), New York: Basic Books, 2013. 